\title{
Comparison of the Drop Weight Impact Performance of Sandwich Panels with Aluminium Honeycomb and Titanium Alloy Micro Lattice Cores
}

\author{
R. Hasan ${ }^{\text {a }}$, R. Mines ${ }^{\text {b }}$, E. Shen, S. Tsopanos, W. Cantwell, W. Brooks and \\ C. Sutcliffe
}

Department of Engineering, University of Liverpool, The Quadrangle, Liverpool L69 3GH, UK

arafidah@liv.ac.uk, ${ }^{b}$ r.mines@liv.ac.uk

Keywords: impact, sandwich, honeycomb, micro-lattice

\begin{abstract}
This paper is a study of the drop weight impact behaviour of small sandwich panels of carbon epoxy skins with aluminium honeycomb and titanium alloy micro-lattice cores. A series of experimental tests have shown that the specific impactor penetration behaviours are similar for both cores. The reasons for this are a result of the detailed deformation and rupture behaviour of the two types of core. The deformation and rupture mechanisms of honeycomb and micro-lattice structures will be discussed in general terms, and these observations will be used to inform discussion of actual deformation and rupture in the panel tests. In this way, micro energy absorbing mechanisms will be related to panel performance, and conclusions on the way forward for improved penetration performance using other core materials and geometries will be identified.
\end{abstract}

\section{Introduction}

Foreign object impact, such as dropped tools and bird strikes, is one of the important subjects to be focused on in the studies of sandwich structures and many discussions have been done on the drop weight impact performance of sandwich panels using various core materials [1-4]. Sandwich core behaviours as an energy absorbing materials have extensively been studied, in order to obtain better crash performance of sandwich structures. The most studied core is honeycomb, specifically aluminium honeycomb, which offers a high stiffness and strength-to-weight ratio, especially in the out-of-plane direction [5]. It is important to understand the mechanics of honeycombs as the basics to other complex core materials of sandwich panels such as foams and lattice structures.

The studies of micro-lattice structures as core materials in sandwich construction have been initiated from the approximation approach of microstructural models for foams. Mines has broadly discussed the behaviour of various foams and micro-lattice structures [6]. Advanced manufacturing techniques such as the rapid prototyping selective laser melting (SLM) technique [7] has strongly contributed to the initial study on the metallic micro-lattice structure at the University of Liverpool. Work has been carried out in studying the mechanical properties, crush behaviours, as well as impact properties of the SLM SS316L stainless steel and Ti64 titanium alloy micro-lattice [6-10]. However, it should be noted that the mechanical properties of the SLM micro-lattice structures are very much influenced by two processing parameters that are laser power (in Watt [W]) and laser exposure time (in micro seconds $[\mu \mathrm{s}]$ ) [11].

Interestingly, it is found that the SLM micro-lattice structure manufactured from the Ti64 is competitive with aluminium honeycomb in specific strength [12]. It is also shown that strength and impact failure load of Ti64 micro-lattice is better than that of SS316L micro-lattice. There was a reduction in dent depth for a given impact energy for the Ti64 [13]. However, a major issue with micro lattice technology is the synthesis of optimal configurations. Therefore, theoretical and numerical parametric models are required to systematically vary such parameters as micro strut architecture, strut aspect ratio, cell size, parent material and rate of loading [14]. Also, a closer 
comparison study with the main competitor as sandwich construction core, which is the aluminium honeycomb, is also required in understanding the energy absorption capabilities and damage mechanisms of the micro-lattice structure.

In this paper, the results from drop weight impact test of small sandwich panels with aluminium honeycomb and Ti64 micro-lattice cores using carbon epoxy skins are going to be discussed. The experimental results have shown that the specific impactor penetration behaviours are similar for both cores [15]. Therefore, comparison and understanding on their failure deformations and micro mechanisms is important in future improvement on performance of different core materials and geometries.

\section{Impact Test on Sandwich Structures}

Impact Test. The drop weight impact test has been carried out on $100 \mathrm{~mm} \times 100 \mathrm{~mm} \times 20 \mathrm{~mm}$ core size sandwich panels with two different core materials as detailed in Table 1. In this study, the full definition of manufacturing parameters [11] for the Ti64 micro-lattice is: architecture $=$ BCC, parent material $=$ Ti64, laser power $=200 \mathrm{~W}$, exposure time $=1000 \mu \mathrm{s}$, strut diameter $=400 \mu \mathrm{m}$, cell size $=$ $2.5 \mathrm{~mm}$ and unit cell $=$ cubic $(\mathrm{BCC} / \mathrm{Ti64} / 200 / 1000 / 400 / 2.5 / \mathrm{Cubic})$.

Table 1: Details of sandwich panels

\begin{tabular}{|c|c|c|c|c|c|}
\hline \multicolumn{6}{|l|}{ Skin details } \\
\hline $\begin{array}{l}\text { Prepreg } \\
\text { material }\end{array}$ & Skin lay-up & $\begin{array}{c}\text { Areal } \\
\text { density } \\
{\left[\mathrm{g} / \mathrm{m}^{2}\right]}\end{array}$ & $\begin{array}{c}\text { Tensile } \\
\text { modulus (8 } \\
\text { ply laminate) } \\
{[\mathrm{GPa}]}\end{array}$ & $\begin{array}{c}\text { Tensile } \\
\text { strength (8 ply } \\
\text { laminate) } \\
{[\mathrm{MPa}]}\end{array}$ & Supplier \\
\hline $\begin{array}{l}\text { Plain weave } \\
\text { carbon fibre / } \\
\text { epoxy matrix } \\
(\text { CFRP) }\end{array}$ & $\begin{array}{c}4 \text { ply - } \\
\text { Nominal } \\
\text { thickness } \\
1.1 \mathrm{~mm}\end{array}$ & $410 \pm 15$ & 58 & 850 & $\begin{array}{c}\text { Gurit } \\
\text { (EP121-C15-53) }\end{array}$ \\
\hline \multicolumn{6}{|l|}{ Core details } \\
\hline Name & Parent material & $\begin{array}{l}\text { Density } \\
{\left[\mathrm{g} / \mathrm{cm}^{3}\right]}\end{array}$ & $\begin{array}{l}\text { Cell type / } \\
\text { edge length } \\
{[\mathrm{mm}]}\end{array}$ & $\begin{array}{c}\text { Manufacturing } \\
\text { parameters }\end{array}$ & Supplier \\
\hline $\begin{array}{l}\text { Aluminium } \\
\text { honeycomb }\end{array}$ & $\begin{array}{l}\text { Aluminium } \\
\text { alloy } 5056\end{array}$ & 2.63 & $\begin{array}{l}\text { Hexagon open } \\
\text { / } 8\end{array}$ & - & $\begin{array}{c}\text { Hexcel } \\
\text { (CRIII-1/4-5056- } \\
.001 \mathrm{~N}-2.3)\end{array}$ \\
\hline $\begin{array}{c}\text { Titanium alloy } \\
\text { micro-lattice }\end{array}$ & $\begin{array}{c}\text { Titanium alloy } \\
\text { Ti } 6 \mathrm{Al} 4 \mathrm{~V} \\
\end{array}$ & 4.43 & $\begin{array}{c}\text { BCC open / } \\
2.5 \\
\end{array}$ & $\begin{array}{c}\text { SLM 200W x } \\
1000 \mu \mathrm{s} \\
\end{array}$ & $\begin{array}{c}\text { TLS Technik } \\
\text { (Grade } 5 \text { ASTM) }\end{array}$ \\
\hline
\end{tabular}

The sandwich structures were formed by stacking four plies of CFRP prepreg as the upper and lower skin of each core material, and compression moulded using a hot press machine. The pressure was maintained below the yield stress of the core materials at a controlled temperature of $125^{\circ} \mathrm{C}$ for two hours. There was no adhesive used at the skin-core interface, since the process had allowed the prepreg resin to flow over the core material, and bonded them together.

The impact test has been conducted on the instrumented drop-weight impact tower. An instrumented carriage with the hemispherical tip impactor of $10 \mathrm{~mm}$ diameter was released from a certain height, in order to give a certain amount of impact energy on the sandwich panel. The velocity of the impactor during the impact event was measured using a high speed camera, and the velocity versus time traces from the velocimeter was recorded by a computer to produce displacement versus time traces. The impacted sandwich panels were supported at their four corners. 
Impact Test Results. Table 2 summarizes the impact test results of aluminium honeycomb and Ti64 micro-lattice cores which led to the calculation of specific impact energy. On the other hand, Figure 1 compares graphically, the difference in specific impact energy versus dent depth for aluminium honeycomb and Ti64 micro-lattice cores, together with the other two types of cores that had been compared elsewhere [15], the stainless steel micro-lattice (BCC/SS316L/140/500/200/2.5/Cubic) and aluminium foam (Alporas) cores. By looking at the dent depth, it is shown that at lower specific impact energy, the aluminium honeycomb is more than two times better in impact resistance, as compared to the Ti64 micro-lattice. However, at higher specific impact energy, the gap difference between the dent depths of both cores is becoming smaller.

Table 2: Impact test results of sandwich panels with aluminium honeycomb (honeycomb) and titanium alloy (Ti64) micro-lattice cores

\begin{tabular}{|c|ccc|c|c|c|c|c|}
\hline Core & $\begin{array}{c}\text { Drop } \\
\text { height } \\
{[\mathrm{m}]}\end{array}$ & $\begin{array}{c}\text { Dent } \\
\text { depth } \\
{[\mathrm{mm}]}\end{array}$ & $\begin{array}{c}\text { Absorbed } \\
\text { energy } \\
{[\mathrm{J}]}\end{array}$ & $\begin{array}{c}\text { Panel } \\
\text { mass } \\
{[\mathrm{g}]}\end{array}$ & $\begin{array}{c}\text { Panel } \\
\text { thickness } \\
{[\mathrm{mm}]}\end{array}$ & $\begin{array}{c}\text { Drop } \\
\text { mass } \\
{[\mathrm{kg}]}\end{array}$ & $\begin{array}{c}\text { Volumetric } \\
\text { density } \\
{\left[\mathrm{kg} / \mathrm{m}^{3}\right]}\end{array}$ & $\begin{array}{c}\text { Specific } \\
\text { impact } \\
\text { energy } \\
{\left[\mathrm{Jm}{ }^{3} / \mathrm{kg}\right]}\end{array}$ \\
\hline \multirow{3}{*}{ Honeycomb } & 0.50 & 19.08 & 11.90 & 42.28 & 21.10 & 2.07 & 200.4 & 0.051 \\
\cline { 2 - 9 } & 0.25 & 2.25 & 5.13 & 41.82 & 21.55 & 2.03 & 194.1 & 0.026 \\
\cline { 2 - 9 } & 0.37 & 10.77 & 7.85 & 41.87 & 21.50 & 2.03 & 194.7 & 0.038 \\
\cline { 2 - 9 } & 0.45 & 15.69 & 9.47 & 41.70 & 21.60 & 2.03 & 193.1 & 0.046 \\
\hline \multirow{3}{*}{ Ti64 } & 1.00 & 18.80 & 21.29 & 96.10 & 21.90 & 2.08 & 438.8 & 0.046 \\
\cline { 2 - 9 } & 0.25 & 3.27 & 5.58 & 95.90 & 21.30 & 2.07 & 450.2 & 0.011 \\
\cline { 2 - 9 } & 0.50 & 4.78 & 10.68 & 95.90 & 21.30 & 2.07 & 450.2 & 0.023 \\
\cline { 2 - 8 } & 0.75 & 12.03 & 16.03 & 94.70 & 21.10 & 2.07 & 448.8 & 0.034 \\
\hline
\end{tabular}

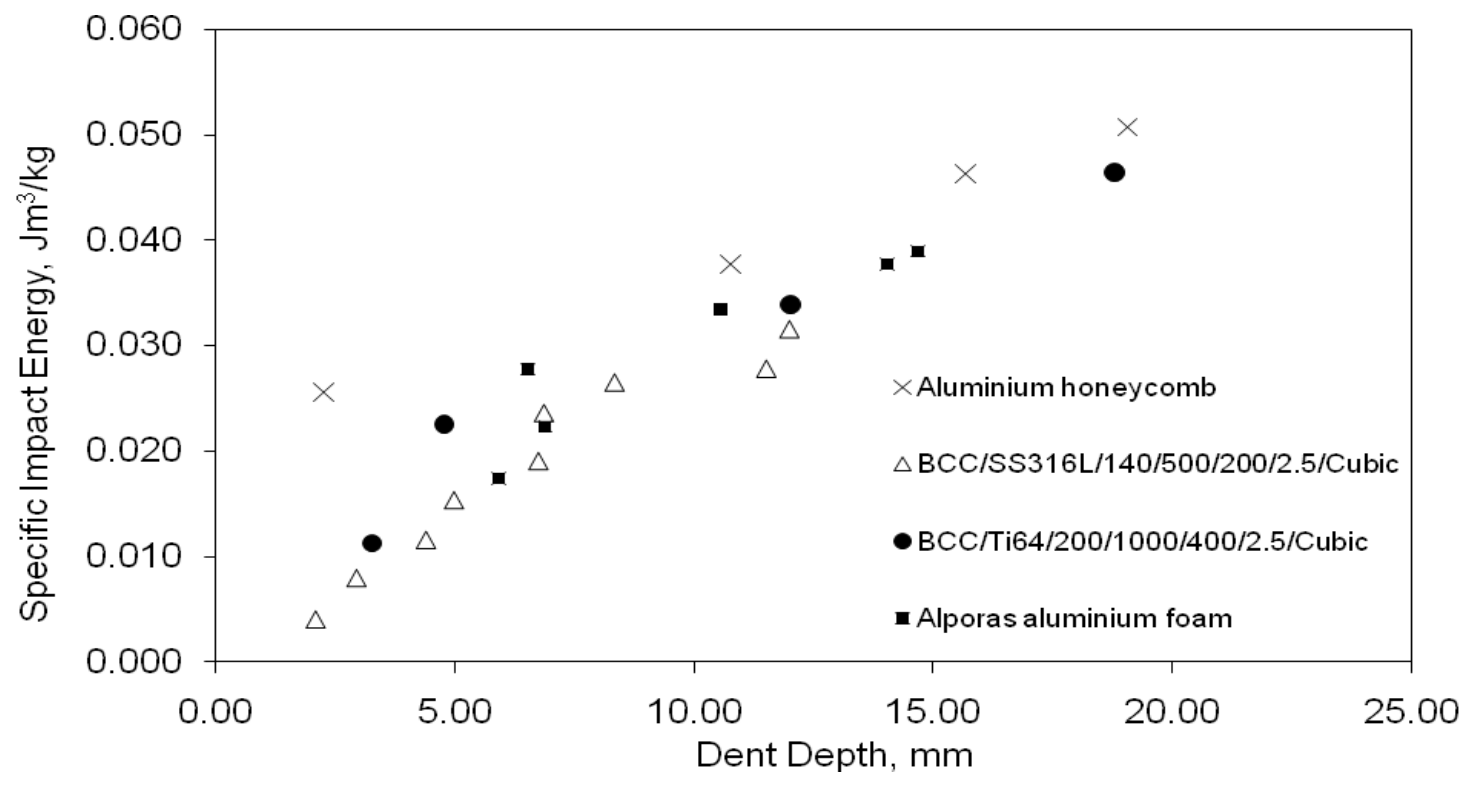

Figure 1: Difference in specific impact energy versus dent depth of Ti64 micro-lattice and aluminium honeycomb cores, together with SS316L micro-lattice and Alporas foam

\section{Discussions on Deformation of Impacted Sandwich Panels}

Aluminium Honeycomb Panel. Figure 2 shows CT scan images of side, top and 3-D view for impacted aluminium honeycomb sandwich panels. From the 3-D image, it can be observed that the affected diameter of the impacted region would be approximately twice that of the impactor size. This is supported by the side view observation that shows that there seems to be slight skin bending 
and honeycomb panel buckling around the impacted area. The impacted skin was fractured and cells in the region experienced similar crush behaviour with honeycomb cells under compression. There was also no visible skin-core separation observed in the honeycomb panel. Although it is reported that delamination occurred in the upper skin when the incident impact energy was more than 5J [3], further micrographic analysis needs to be done in this study for observing the delamination behaviour of the skin. For the core, around three to four hexagonal cells at the surrounding region were affected. This is due to the buckling and bending phenomena especially at the top region of the honeycomb panels, under the upper skin. From the deformation that can be observed in the CT scan images, it is suggested that the impact energy was absorbed in the aluminium honeycomb panel by upper skin bending, skin fracture, core crushing, core tearing, core buckling, core bending and core folding in the impacted and surrounding region. Figure 3 illustrates the deformation mechanisms of a unit cell for aluminium honeycomb, to further assist the understanding.

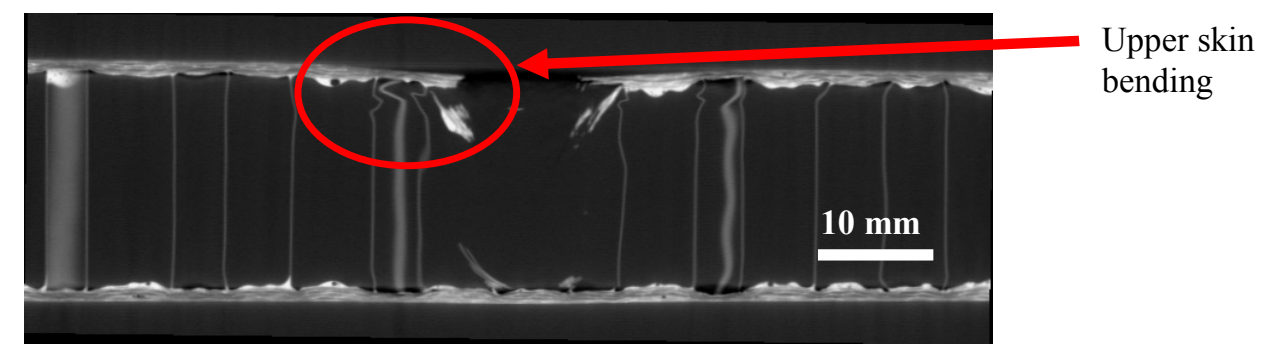

(a)

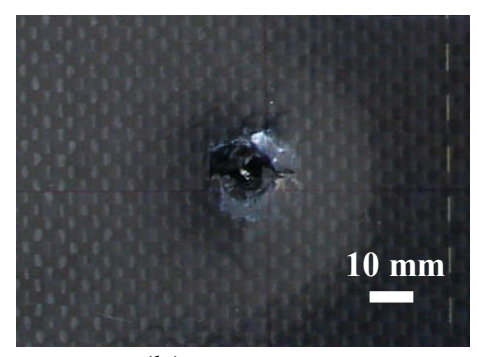

(b)

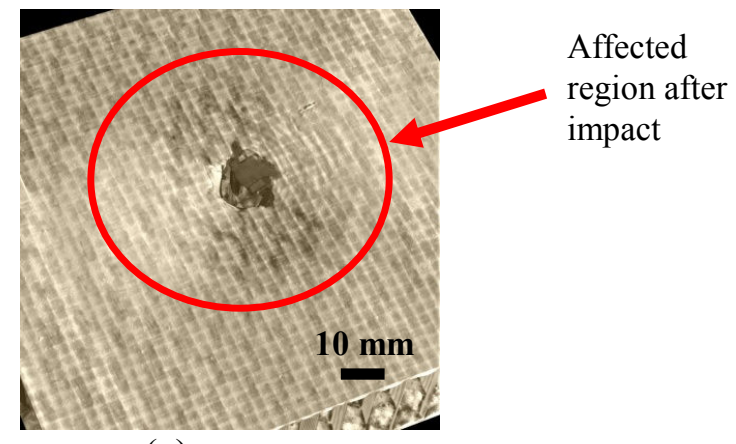

(c)

Figure 2: CT scan images of (a) side, (b) top and (c) 3-D view for impacted aluminium honeycomb sandwich panel

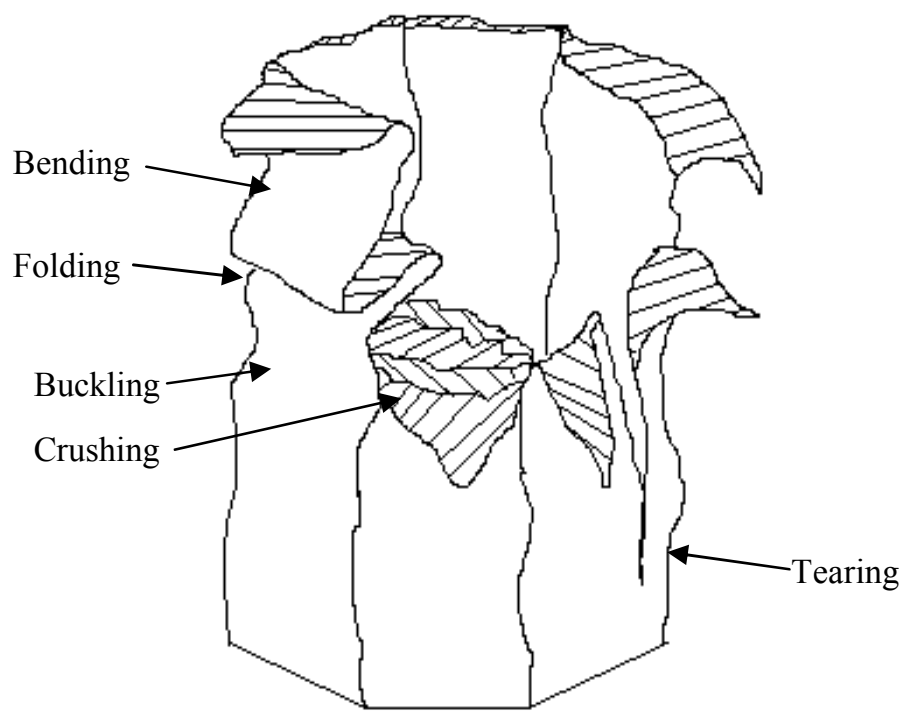

Figure 3: Illustration on the deformation mechanisms of a unit cell for aluminium honeycomb 
Titanium Alloy Micro-Lattice Structure Panel. Figure 4 shows CT scan images of top and side view for impacted Ti64 micro-lattice core sandwich panels. It can be observed that localised skin damage and indentation occurred in this panel, rather than globalised damage as occurred in the aluminium honeycomb panels. The damage area is about the same size of the impactor which penetrated and fractured the skin. The area beyond that seems to be not affected by the impact incidence. No evidence of delamination in the skin was observed but there was debonding of the skin from the core at the fractured region. It can be also seen that the struts under the impacted skin have been fractured and fragmented in brittle manner. From the deformation of this impacted Ti64 micro-lattice core panel, it can be suggested that the impact energy was absorbed by the skin fracture, core-skin debonding and micro struts fractured in brittle manner. There were also a few micro struts that experienced slight bending, which most likely occurred prior to strut failure, since there was no strong evidence indicating ductile failure occurred at the same time as brittle failure. Figure 5 illustrates the brittle fracture of impacted micro struts for a unit cell Ti64 micro-lattice structure, to further assist the understanding.

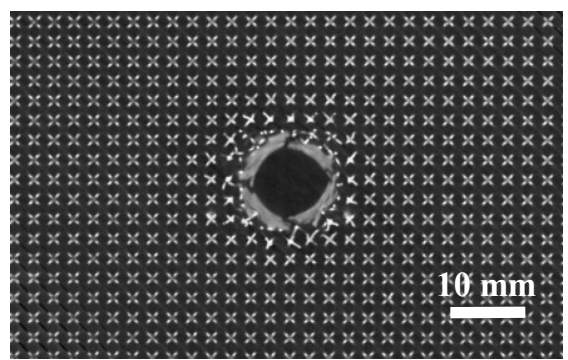

(a)

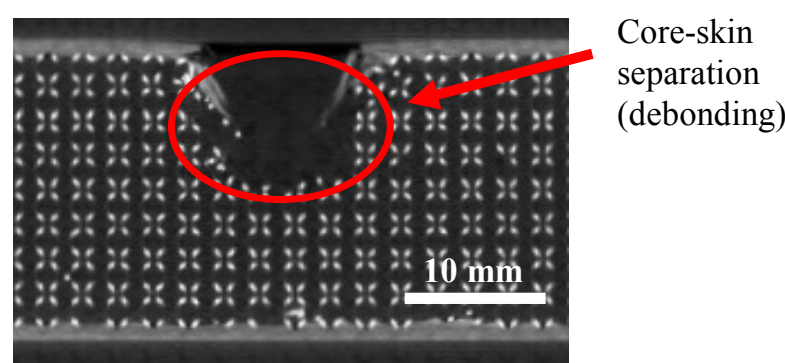

(b)

Figure 4: CT scan images of (a) top and (b) side view for impacted Ti64 micro-lattice core sandwich panel (impact energy $=22.98 \mathrm{~J})$

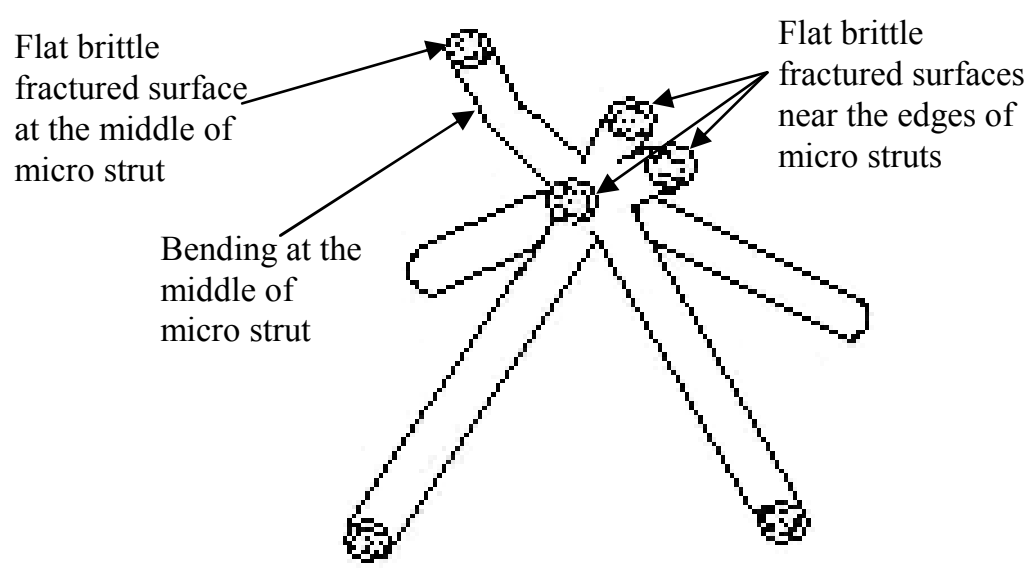

Figure 5: Illustration on brittle fracture of impacted micro struts for a unit cell Ti64 micro-lattice structure

\section{Concluding Remarks}

In comparison, both aluminium honeycomb and Ti64 micro-lattice cores show comparable impact resistance, from the similar result obtained for dent depth at high specific impact energy. However, damage area seems to be more localised for the Ti64 micro-lattice as compared to that of aluminium honeycomb. It is due to the different mechanisms during impact energy absorption in both cores. This can be an advantage for the Ti64 micro-lattice, and it needs to be further studied and analysed for the potential as one of the aluminium honeycomb competitors that can be used in aerospace applications. There is a requirement outlined by the aircraft manufacturer that the impact 
damage is preferably to have similar diameter with the impactor [16]. The localised impact damage means that there would be less replacement area needed for a particular sandwich structure.

Besides showing a good impact resistance which is comparable with aluminium honeycomb, the Ti64 micro-lattice shows unfavourable brittle failure, and this issue needs to be addressed and improvement should be done in order to have a more stable impact energy absorption behaviour. It should be noted that there is potential for SLM Ti64 micro-lattice structure to be optimized and have graded topology $[6,14]$ for better impact resistance.

\section{Acknowledgements}

Financial support from grants sponsored by EPSRC/EP/C009525/1, EPSRC/EP/009398/1 and EU FP6 CELPACT is gratefully acknowledged. The authors would like to acknowledge Dr A Johnson from DLR Stuttgart, Germany for CT scans and Prof. X. Wu from University of Birmingham for post manufacture HIP process of Ti64. R. Hasan would like to thank Malaysian Government and Universiti Teknikal Malaysia Melaka for her PhD study sponsorship.

\section{References}

[1] R.A.W. Mines, C.M. Worrall and A.G. Gibson: Composites Vol. 25 (1994), p. 95-110

[2] C.G. Kim and E.J. Jun: J. Compos. Mater. Vol. 26 (1992), p. 2247-2261

[3] M. Akay and R. Hanna: Composites Vol. 21(4) (1990), p. 325-331

[4] S. McKown and R.A.W. Mines: High Performance Structures and Materials II Vol. 7 (2004), p. $37-46$

[5] L.J. Gibson and M.F. Ashby: Cellular solids: structure and properties $-2^{\text {nd }}$ ed. (Cambridge University Press, Cambridge United Kingdom 1999).

[6] R.A.W. Mines: Strain. Vol. 44(1) (2008), p. 71-83

[7] M. Santorinaios, W. Brooks, C.J. Sutcliffe, R.A.W. Mines: WIT Trans. Built Environ. Vol. 85 (2006), p. 481-490

[8] S. McKown, W.J. Cantwell, W.K. Brooks, R.A.W. Mines, S. Tsopanos, C.J. Sutcliffe: Proceedings of the $28^{\text {th }}$ International European SAMPE, Europe (2007), p. 396-401

[9] R.A.W. Mines, S. McKown, S. Tsopanos, Y. Shen, W.J. Cantwell, W.J. Brooks, C. Sutcliffe: Applied Mechanics and Materials Vol. 13-14, (2008), p. 85-90

[10] S. McKown, Y. Shen, W. Brooks, W.J. Cantwell, C. Sutcliffe, G. Langdon, G.N. Nurick: Int J. Imp. Engrg. 35, (2008), p. 795-810

[11] S. Tsopanos, R. Mines, S. McKown, Y. Shen, W. Cantwell, W. Brooks, C.J. Sutcliffe: Submitted to Journal of Manufacturing Science and Engineering ASME (2009)

[12] R. Mines, Y. Girard, V. Fascio: Proceedings of the International European SAMPE, Europe (2009), p. 248-256

[13]R. Mines, S. Tsopanos, E. Shen, S. McKown, W.J. Cantwell: Proceedings of the ICCM17 Conference, Edinburgh United Kingdom (2009), Paper No. B6.1

[14] K. Ushijima, W.J. Cantwell, R.A.W. Mines, S. Tsopanos, M. Smith: To be published Journal of Sandwich Structures and Materials (2010)

[15] Y. Shen: PhD Thesis, University of Liverpool, United Kingdom (2009)

[16]E. Morteau and C. Fualdes: FAA Workshop for Composite Damage Tolerance and Maintenance, National Institute for Aviation Research, Chicago USA (2006) 